\title{
G Protein Receptor Kinase Type 2: A Novel Target in Cardiovascular Drug Development
}

\author{
Marko S. Vasić, Nina M. Japundžić-Žigon \\ Institute for Pharmacology, Clinical Pharmacology and Toxicology, Faculty of Medicine, \\ University of Belgrade, Belgrade, Serbia
}

\section{SUMMARY}

In spite of significant advancement in pharmacotherapy, heart failure remains one of the main causes of death worldwide. The existing treatment of heart failure prolongs life span by slowing down the pathological process but does not induce heart healing. The $\beta$ adrenergic receptor dysfunction is a hallmark abnormality of advanced stages of heart failure, and increased expression of G-protein-coupled receptor kinase 2 (GRK-2) involved in down regulation of $\beta$ adrenergic receptors, occurs in early stages of heart failure. Thus a new drug candidate, an inhibitor of G-protein-coupled receptor kinase 2 ( $\beta A R K c t$ ) that prevents $\beta A R$ down-regulation and desensitization, is being developed. Experimental data are encouraging.

Keywords: heart failure; $\beta$ adrenergic receptor; $G$ protein kinase 2 inhibitor

\section{INTRODUCTION}

Despite of significant progress of pharmacotherapy in last decades of the 20th century, heart failure remains a leading cause of death worldwide [1]. The quality of life and the life span are extended by the use of drugs that modify the function of the renin-angiotensin-aldosterone system, diuretics and beta adrenergic receptor blockers. Nevertheless these drugs neither induce regression nor the healing of the myocardium.

It has been largely acknowledge that the dysfunction of beta-adrenergic receptors $(\beta A R)$ is the major mechanism in the development of advanced stages of heart failure. The enhanced sympathetic outflow associated with heart failure and the increased release of noradrenaline from sympathetic nerve endings in the heart, induce down-regulation and desensitization of $\beta A R$ receptors. The reduction in the number of $\beta A R$ in the failing heart contributes importantly to the decrease of its contractile force.

Numerous experimental findings suggest that $\beta$ ARKct by preventing the down-regulation of $\beta$ AR improves myocardial function and reverses pathological changes. In this review, the mechanisms of $\beta$ ARKct action along with experimental and translational studies are described.

\section{Methodology}

Sources of studies included the Medline and SCI databases. The databases were searched from inception to October 30, 2013 for relevant studies using the terms "heart failure", " $\beta$ adrenergic 
receptor", "G protein kinase 2 inhibitor" and synonyms for all three terms. Potentially associated publications were assessed by checking their titles and abstracts and the most relevant publications were subjected to closer examination. The reference lists of the selected papers were also screened for articles that might have been missed in the initial search, and references cited in the identified articles were searched manually. All eligible studies satisfied the following inclusion criteria: experimental and translational studies without language restrictions; a sample size of more than six animals/ humans was required for each comparison group. Studies were excluded based on the following criteria: studies not mentioning $G$ protein kinase 2 inhibitor in the abstract; studies without comparison groups; abstracts presented at conferences, editorials, commentaries, and studies without complete data; cohort studies and case-control studies were excluded.

\section{BETA-ADRENERGIC RECEPTORS AND THE SIGNALING PATHWAY IN THE HEALTHY HEART}

$\beta A R$ is a classical transmembrane receptor with seven transmembrane domains, an amino terminus on the extracellular surface and carboxyl tail on the intracellular surface of the cardiomyocyte. Binding of natural ligands to $\beta A R$ such as adrenaline, noradrenaline, dopamine, or beta-adrenergic agonists such as dobutamine leads to $G$ protein activation. $G$ protein is an intracellular heterotrimer with $\alpha, \beta, \gamma$ subunits. $\alpha$ subunit activates adenylyl cyclase that promotes synthesis of cyclic adenosine monophosphate (cAMP) and the activation of protein kinase A (PKA). PKA phosphorylates phospholamban (cell protein) to prevent calcium-ATPase inhibition that will enable calcium extrusion from sarcoplasmic reticulum and recruit more muscular fibers in contraction, a mechanism underlying positive inotropism.

Under physiological conditions, binding of agonist to $\beta A R$ triggers intracellular mechanisms leading to $\beta A R$ desensitization (Figure 1). Desensitization involves $G$ protein receptor kinase 2 binding to $\beta \gamma$ subunit (G $\beta \gamma$ ) of G protein and its translocation in the membrane of cardiomyocytes, where it phosphorylates $\beta$ AR. Phosphorylation changes the $\beta A R$ conformation that allows the bind of $\beta$ arrestin, clathrin and adaptin. These cytoplasmic proteins act to invaginate the cell membrane and enclose $\beta A R$ in the vesicle while dynamin segregates the vesicle from the membrane to form endosomes, a process well known as endocytosis (Figure 2). The faith of the internalized receptors in endosomes depends on many factors and two pathways are possible: quick recycling, i.e. re-incorporation in the membrane or degradation by fusion with lysosomes.

\section{BETA-ADRENERGIC RECEPTORS ( $\beta A R$ ) AND THE SIGNALING PATHWAY IN THE FAILING HEART}

In the myocardium, there are three types of $\beta$ AR: $\beta A R 1, \beta A R 2$ and $\beta A R 3$ in the ratio 80:18:2. While $\beta$ AR1 receptors mediate effects of catecholamine on the heart, $\beta \mathrm{AR} 2$ receptors
Figure 1. Signaling of $\beta A R$

Left: After agonist binding to $\beta A R$, Ga subunit stimulates the synthesis of cyclic adenosine monophosphate (cAMP) leading to enhanced myocardial contractility.

Right: GRK-2 kinase binds to G $\beta y$ subunit to translocate GRK-2 in the membrane and phosphorylate $\beta A R$ leading to binding of $\beta$-arestin ( $\beta$-arr).

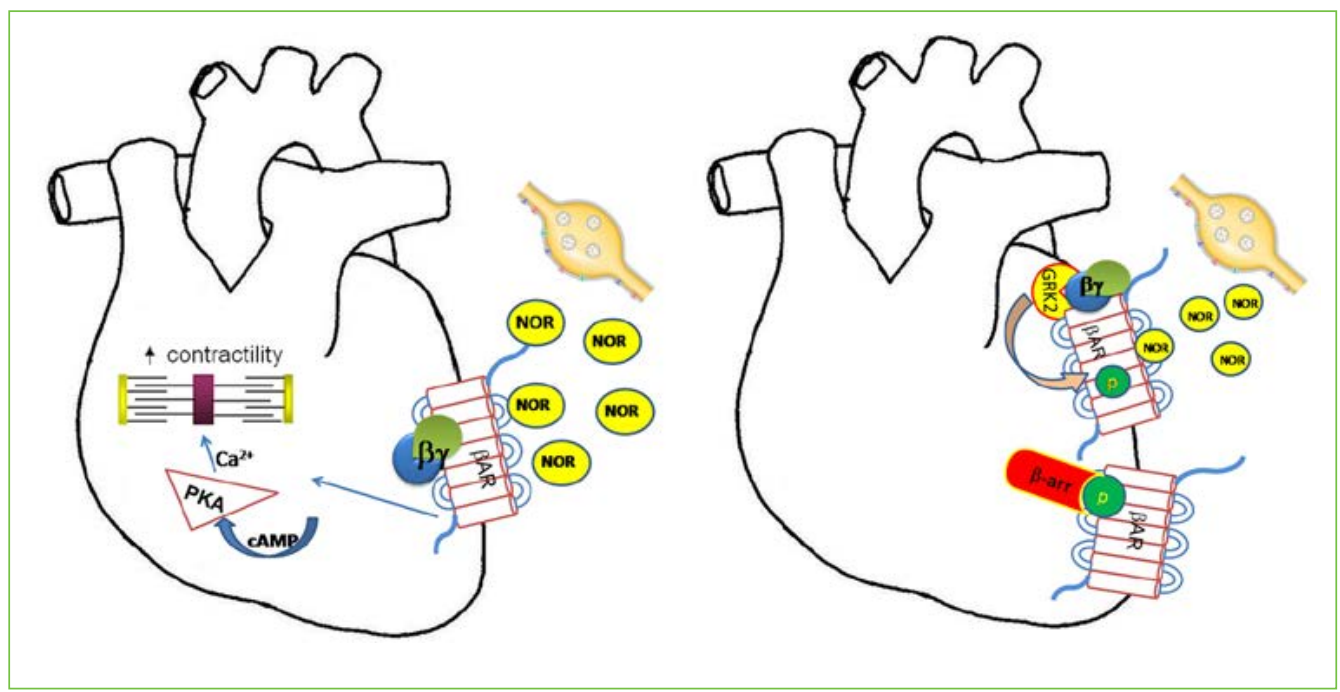




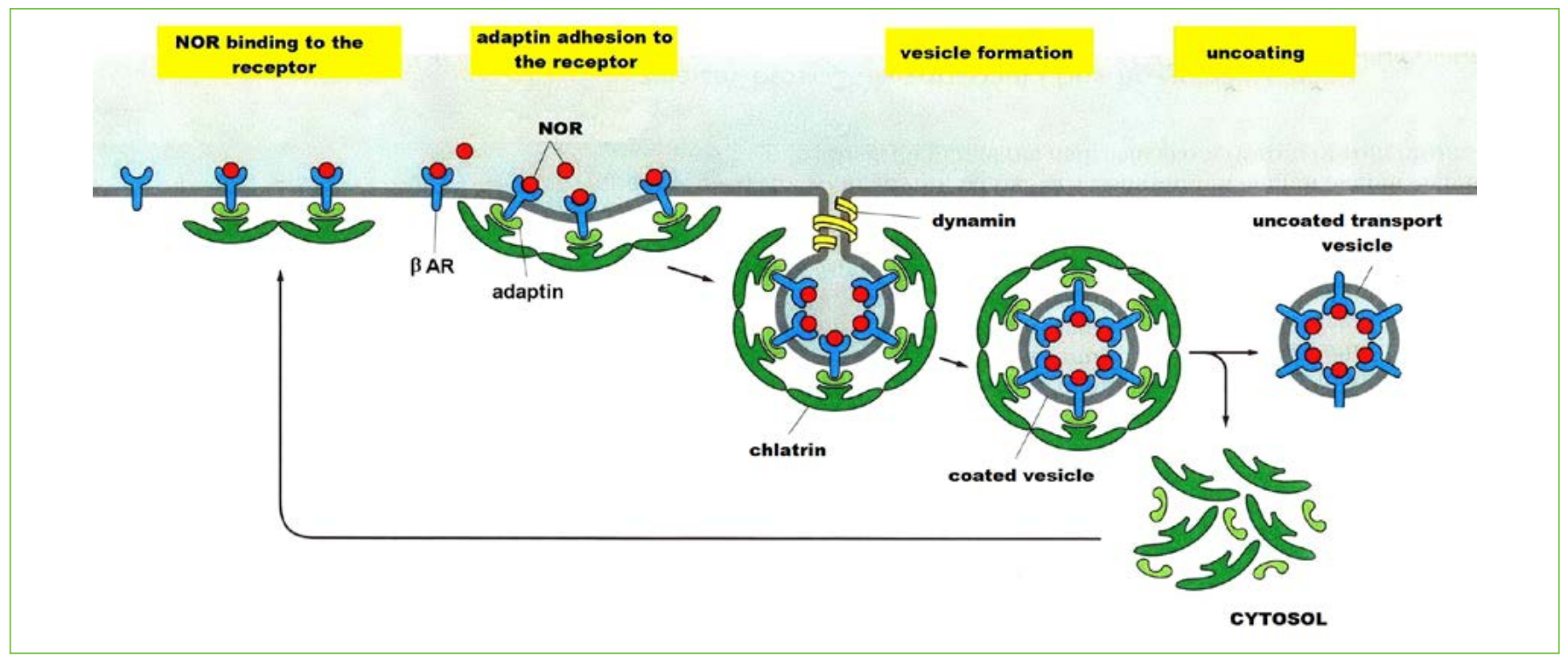

Figure 2. $\beta A R$ internalization

Agonist binding to $\beta A R$ activates adaptin and its binding to the intracellular domain of $\beta A R$. Then clatrin binds to adaptin to form a vesicle and internalize $\beta A R$ (modified from [32]).

are linked to inhibitory $\mathrm{G}$ protein and are considered to exert protective effects on cardiomyocytes $[2,3,4]$. It has been suggested that in the failing heart, the change in $\beta A R 1: \beta A R 2$ to $50: 50$ ratio, and the change in the conformation of $\beta A R$ receptors, contribute to apoptotic mechanism. Even in early stages of heart failure, due to the development of hyperadrenergic state [5-9] and increased stimulation of $\beta$ AR by catecholamines [10-13] boost up GRK-2 expression leading to $\beta \mathrm{AR} 1$ receptor desensitization $[5,6,14,15]$. In the time course of the disease, the reduced number of $\beta$ AR 1 will decrease its contractile force [11]. Therefore the increase of GRK-2 expression has been proposed as an early marker of heart failure $[16,17,18]$.

\section{GRK-2 inhibitor ( $\beta A R K c t)$ in experimental models of heart failure}

GRK-2 inhibitor is the carboxyl part of the GRK-2 chain. Its mechanism of action is based on the competitive binding to $\beta \gamma$ subunit of $G$ protein and displacement of GRK-2 from the $\mathrm{G} \beta \gamma$.

The role of GRK-2 in the development of heart failure was demonstrated in genetic experimental models of heart failure. In knockout (KO) mice deletion of the gene for the muscle LIM domain protein - MLP [19] induce heart failure. Also, over-expression of calsequestrin, a calcium binding protein in mice induces heart failure [20]. Administration of $\beta$ ARKct to both models of KO mice prevented the development of heart failure and extended the life span of $\mathrm{KO}$ mice. Moreover, experimental data indicate that co-administration of beta-blockers and $\beta$ ARKct had synergetic beneficial effects in experimentally-induced heart failure [20].

Deletion of GRK-2 gene in mice has been shown to be associated with embryonic death [21], indicating that GRK-2 is essential for heart organogenesis. In heterozygous GRK-2 KO mice (which have 50\% expression of GRK-2 genes) concomitantly transfected with $\beta$ ARKct, the contractile force of the heart and $\beta A R$ reserve were enhanced [22]. In heterozygous GRK-2 KO mice exposed to anterior coronary artery ligation (an experimental model of myocardial necrosis) a mortality rate was reduced [23]. In the same study, GRK-2 gene deletion was demonstrated to be more effective than pharmacological blockade of $\beta$ AR.

\section{TRANSLATIONAL STUDIES - FROM ANIMALS TO HUMANS}

$\beta A R K c t$ has a negative ADME (adsorption, distribution, metabolism and excretion) profile and is thus hardly deliverable to the heart cells both in vivo and in vitro (Figure 3). Therefore, vectors modified non replicant viruses, whose genome contain a therapeutic gene instead of the protein capsid gene, were used to deliver 
$\beta A R K c t$ to cells. Adenoviral transfection with $\beta A R K c t$ in cardiomyocytes has been shown to be effective in animal models of heart failure $[24,25,26]$. Adenoviral $\beta$ ARKct gene delivery by intra-cardiac injection to rabbit hearts in experimentally-induced necrosis of myocardial tissue by ligation has been shown to prevent remodeling of left ventricle $[27,28]$. Two protocols of gene therapy in humans, in 2008 [29] and in 2009 [30] indicate that adenoviral and adeno-associated viral transfections are not harmful to humans.

\section{New indication for an old drug?}

Paroxetine is an antidepressant drug, selective serotonin inhibitor, registered worldwide since 1992. Recently, a group of researchers from Michigan, New York and Pennsylvania [31] identified it as a potent direct inhibitor of GRK2. Maximal GRK-2 inhibition by paroxetine was reported to be at doses higher by 1-2 powers on log scale. Experimental data showed that paroxetine increases cardiac inotorpism both in vitro and in vivo while fluoxetine, a related drug, does not because it is deprived of the ability to inhibit GRK-2. In the post-marketing period of paroxetine, there were reports that mothers treated with paroxetine during pregnancy, delivered children with cardiovascular defects, suggesting that this teratogenic effect of paroxetine could be related to the inhibition of GRK-2.
Thus, clinical studies aimed at evaluating the outcome of patients suffering from heart failure on chronic paroxetine treatment (phase IV clinical trials) are desirable.

\section{CONCLUSIONS}

G protein kinase-2 inhibitor is a promising novel target for new drug development in advanced stages of heart failure associated with down regulation of $\beta$ adrenergic receptors. The use of the peptide inhibitor is hindered by the development of more effective and harmless gene delivery systems. Meanwhile, the investigation of the effectiveness of paroxetine in heart failure (phase IV clinical studies) and the synthesis of related molecules may be a quicker way to approach the development of new drugs.

\section{Conflict of Interest Statement}

Authors declare no conflict of interest.

\section{REFERENCES}

1. McMurray J, Adamopoulos S, Anker SD, Auricchio A, Böhm M, Dickstein K, et al. ESC guidelines for the diagnosis and treatment of acute and chronic heart failure 2012: The Task Force for the Diagnosis and Treatment of Acute and Chronic Heart Failure 2012 of the European Society of Cardiology. Developed in collaboration with the Heart Failure Association (HFA) of the ESC. Eur J
Figure 3. Adenoviral transfection

Adenoviral vector infects cardiomyocyte by endocytosis. Its plasmid reaches the nucleus and then starts the transcription of $\beta$ ARKct.

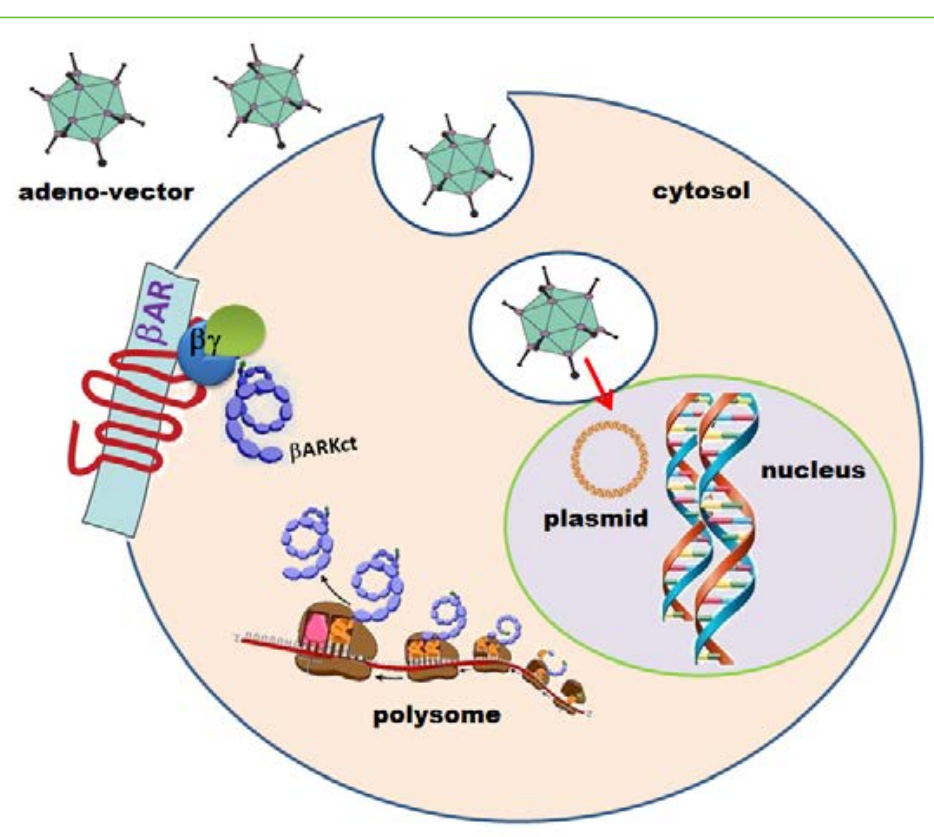

Volume 1・Number 2・May 2014 HOPH 
Heart Fail. 2012; 14(8):803-69. (Erratum in: Eur J Heart Fail. 2013; 15(3):361-2).

2. Communal C, Singh K, Sawyer DB, Colucci WS. Opposing effects of $\beta 1$ - and $\beta 2$ - adrenergic receptors on cardiac myocyte apoptosis: role of a pertussis toxin sensitive $\mathrm{G}$ protein. Circulation. 1999; 100:2210-2.

3. Chesley A, Lundberg MS, Asai T, Xiao RP, Ohtani $\mathrm{S}$, Lakatta EG, et al. The $\beta 2$-adrenergic receptor delivers an antiapoptotic signal to cardiac myocytes through Gi-dependent coupling to phosphatidylinositol 3-kinase. Cir Res. 2000; 87:1172-9.

4. Zhu WZ, Zheng M, Koch WJ, Lefkowitz RJ, Kobilka BK, Xiao RP. Dual modulation of cell survival and cell death by â2-adrenergic signaling in adult mouse cardiomyocytes. Proc Natl Acad Sci USA. 2001; 98:1607-12.

5. Petrofski JP, Koch WJ. The $\beta$-adrenergic receptor kinase (BARK1) in heart failure. J Moll Cell Cardiol. 2003; 35:1167-74.

6. Harris CA, Chuang T, Scorer CA. Expression of GRK2 is increased in the left ventricles of cardiomyopathy hamsters. Basic Res Cardiol. 2001; 96:364-8.

7. Yi XP, Gerdes AM, Li F. Myocyte redistribution of GRK2 and GRK5 in hypertensive, heart-failureprone rats. Hypertension. 2002; 39:1058-63.

8. Ungerer M, Böhm M, Elce JS, Erdmann E, Lohse MJ. Altered expression of $\beta$-adrenergic receptor kinase and $\beta 1$-adrenergic receptors in the failing human heart. Circulation. 1993; 87:454-63.

9. Dzimiri N, Muiya P, Andres E, Al-Halees Z. Differential functional expression of human myocardial G protein receptor kinases in left ventricular cardiac diseases. Eur J Pharmacol. 2004; 489:167-77.

10. Rockman HA, Koch WJ, Lefkowitz RJ. Seventransmembrane-spanning receptors and heart function. Nature. 2002; 415:206-12.

11. Lymperopoulos A, Rengo G, Koch WJ. Adrenal adrenoceptors in heart failure: fine-tuning cardiac stimulation. Trends Mol Med. 2007; 13:503-11.

12. Packer $M$. The development of positive inotropic agents for chronic heart failure: how have we gone astray? J Am Coll Cardiol. 1993; 22:119A26A.

13. Bristow MR. $\beta$-adrenergic receptor blockade in chronic heart failure. Circulation. 2000; 101:55869.

14. Brodde OE. Beta-adrenoceptors in cardiac disease. Pharmacol Ther. 1993; 60:405-30.

15. Bristow MR, Ginsburg R, Umans V, Fowler M, Minobe W, Rasmussen R, et al. $\beta 1$-and $\beta 2$-adrenergic-receptor subpopulations in nonfailing and failing human ventricular myocardium: coupling of both receptor subtypes to muscle contraction and selective $\beta 1$ receptor down-regulation in heart failure. Circ Res. 1986; 59: 297-309.

16. Iaccarino G, Barbato E, Cipolletta E, De Amicis V, Margulies KB, Leosco D, et al. Elevated myocardial and lymphocyte GRK2 expression and activity in human heart failure. Eur Heart J. 2005; 26:1752-8.

17. Hata JA, Williams ML, Schroder JN, Lima B, Keys JR, Blaxall BC, et al. Lymphocyte levels of GRK2 (BARK1) mirror changes in the LVAD-supported failing human heart: lower GRK2 associated with improved $\beta$-adrenergic signaling after mechanical unloading. J Card Fail. 2006; 12:360-8.

18. Bonita RE, Raake PW, Otis NJ, Chuprun JK, Spivack T, Dasgupta A, et al. Dynamic changes in lymphocyte GRK2 levels in cardiac transplant patients: a biomarker for left ventricular function. Clin Transl Sci. 2010; 3:14-8.

19. Rockman HA, Chien KR, Choi DJ, laccarino G, Hunter JJ, Ross Jr J, et al. Expression of a $\beta$-adrenergic receptor kinase 1 inhibitor prevents the development of myocardial failure in gene-targeted mice. Proc Natl Acad Sci USA. 1998; 95:7000-5.

20. Harding VB, Jones LR, Lefkowitz RJ, Koch WJ, Rockman HA. Cardiac $\beta$ ARK1b inhibition prolongs survival and augments $\beta$ blocker therapy in a mouse model of severe heart failure. Proc Natl Acad Sci USA. 2001; 98:5809-14.

21. Jaber M, Koch WJ, Rockman H, Smith B, Bond RA, Sulik KK, et al. Essential role of $\beta$ - adrenergic receptor kinase 1 in cardiac development and function. Proc Natl Acad Sci USA. 1996; 93:12974-9.

22. Rockman HA, Choi DJ, Akhter SA, Jaber M, Giros B, Lefkowitz RJ, et al. Control of myocardial contractile function by the level of $\beta$-adrenergic receptor kinase 1 in gene-targeted mice. J Biol Chem. 1998; 273:18180-4.

23. Raake PW, Vinge LE, Gao E, Boucher M, Rengo G, Chen $X$, et al. G protein-coupled receptor kinase 2 ablation in cardiac myocytes before or after myocardial infarction prevents heart failure. Circ Res. 2008; 103:413-22.

24. Drazner MH, Peppel KC, Dyer S, Grant AO, Koch WJ, Lefkowitz RJ. Potentiation of $\beta$-adrenergic signaling by adenoviral-mediated gene transfer in adult rabbit ventricular myocytes. J Clin Invest. 1997; 99:288-96.

25. Akhter SA, Skaer CA, Kypson AP, McDonald PH, Peppel KC, Glower DD, et al. Restoration of $\beta$-adrenergic signaling in failing cardiac ventricular myocytes via adenoviral-mediated gene transfer. Proc Natl Acad Sci USA. 1997; 94:12100-5.

26. Williams ML, Hata JA, Schroder J, Rampersaud E, Petrofski J, Jakoi A, et al. Targeted $\beta$-adrenergic receptor kinase (BARK1) inhibition by gene transfer in failing human hearts. Circulation. 2004; 109:1590-3.

27. White DC, Hata JA, Shah AS, Glower DD, Lefkowitz RJ, Koch WJ. Preservation of myocardial $\beta$-adrenergic receptor signaling delays the development of heart failure after myocardial infarction. Proc Natl Acad Sci USA. 2000; 97:5428-33.

28. Shah AS, White DC, Emani S, Kypson AP, Lilly RE, Wilson $\mathrm{K}$, et al. In vivo ventricular gene delivery of a $\beta$-adrenergic receptor kinase inhibitor to the failing heart reverses cardiac dysfunction. Circulation. 2001; 103:1311-6.

29. Hajjar RJ, Zsebo K, Deckelbaum L, Thompson C, Rudy J, Yaroshinsky A, et al. Design of a phase $1 / 2$ trial of intracoronary administration of AVV1/ SERCA2a in patients with heart failure. J Card Fail. 2008; 14:355-67.

30. Jaski BE, Jessup ML, Mancini DM, Cappola TP, Pauly DF, Greenberg B, et al. Calcium upregulation by percutaneous administration of gene therapy in cardiac disease (CUPID Trial), a first-in-human phase 1/2 clinical trial. J Card Fail. 2009; 15:171-81.

31. Thal DM, Homan KT, Chen J, Wu EK, Hinkle PM, Huang ZM, et al. Paroxetine is a direct inhibitor of g protein-coupled receptor kinase 2 and increases myocardial contractility. ACS Chem Biol. 2012; 7(11):1830-9.

32. Alberts B, Johnson A, Lewis J, Raff M, Roberts K, Walter P. Molecular Biology of the Cell. New York, NY: Garland Science; 2007. 


\section{Inhibitori G-protein kinaze 2 u lečenju slabosti srca}

Marko S. Vasić, Nina M. Japundžić-Žigon

Institut za kliničku farmakologiju, farmakologiju i toksikologiju, Medicinski fakultet,

Univerzitet u Beogradu, Beograd, Srbija

\section{KRATAK SADRŽAJ}

Pored značajnog napretka farmakoterapije, insuficijencija srca ostaje jedan od vodećih uzroka smrti ljudi. Postojeća farmakoterapija produžava život čoveka, ali ne dovodi do izlečenja. Ključnu ulogu u nastanku uznapredovale insuficijencije srca ima disfunkcija beta adrenergičkih receptora ( $\beta A R$ ) koja se podudara s povećanjem ekspresije G-protein kinaze tip 2 (GRK-2). Novi kandidat za lek u terapiji osoba s insuficijencijom srca je inhibitor GRK-2 (ßARKct), koji sprečava nishodnu regulaciju $\beta A R$ u insuficijenciji srca. $U$ radu su prikazani najnoviji eksperimentalni nalazi koji obećavaju.

Ključne reči: insuficijencija srca; beta adrenergički receptor; inhibitor G-protein kinaze 2 